Research Article

\title{
Effect of Different Activators on Rheological and Strength Properties of Fly Ash-Based Filling Cementitious Materials
}

\author{
Liu Fangfang $(\mathbb{D}$, Feng Xiyang, and Chen Li \\ Yunnan Land and Resources Vocational College, Kunming 650000, China \\ Correspondence should be addressed to Liu Fangfang; liufangfag@yugoco.com
}

Received 25 January 2021; Revised 28 February 2021; Accepted 26 March 2021; Published 7 April 2021

Academic Editor: Lijie Guo

Copyright (c) 2021 Liu Fangfang et al. This is an open access article distributed under the Creative Commons Attribution License, which permits unrestricted use, distribution, and reproduction in any medium, provided the original work is properly cited.

In this paper, lime, gypsum, $\mathrm{NaOH}$, and $\mathrm{Na}_{2} \mathrm{SO}_{4}$ are mainly used to study the activation degree and activation mechanism of fly ash, and L9 $\left(3^{4}\right)$ orthogonal table is used for the orthogonal test. The influence of different activators on the rheological and strength properties of slurry was analyzed. The microstructure and hydration products of fly ash cement cementitious body were studied by SEM and XRD. The results show that the bleeding rate of slurry containing activator fly ash system is between $2.24 \%$ and $3.37 \%$, which is much higher than that of pure cement slurry (9.25\%). Therefore, the addition of this system can improve the fluidity of slurry, and the optimal scheme is $\mathrm{a}_{3} \mathrm{~b}_{2} \mathrm{c}_{2} \mathrm{~d}_{2}$. The results show that the compressive strength of cement with activator fly ash system is much lower than that of pure cement, but the increase of strength is between $31 \%$ and $85 \%$, which is much greater than that of pure cement (35\%-46\%). The optimal scheme is $\mathrm{A}_{2} \mathrm{~B}_{2} \mathrm{C}_{3} \mathrm{D}_{3}$ or $\mathrm{A}_{3} \mathrm{~B}_{2} \mathrm{C}_{3} \mathrm{D}_{3}$ at 3 days and $\mathrm{A}_{1} \mathrm{~B}_{3} \mathrm{C}_{2} \mathrm{D}_{3}$ at 28 days. According to the scanning results of SEM and XRD, the addition of activator can significantly improve the hydration degree of fly ash and form a more complex network structure without obvious gap.

\section{Introduction}

tWith the development of mining technology, filling method is considered a future development direction for an increasing number of large, medium, and small mines, and the reduction of filling cost has always been the research emphasis of scholars all over the world $[1,2]$. Fly ash mainly refers to fine particles generated from coal combustion, the particle size of which is $1-100 \mathrm{~m}$ and the main chemical compositions are $\mathrm{SiO}_{2}$ and $\mathrm{Al}_{2} \mathrm{O}_{3}$ [3]. By the end of 2020 , the annual production of fly ash in China has reached 580 million tons. If the fly ash is released into the air, it will seriously affect the air quality, but if it is stacked on the ground, it will not only pollute the local environment but also inevitably cause a waste of resources. Since fly ash is enriched with $\mathrm{Si}, \mathrm{Al}, \mathrm{Ca}$, and other chemical substances [4], it can be used to substitute some types of cement in the fields of concrete $[5,6]$ or mine filling [7-9]. This is a generally accepted treatment method. However, as an inert material, fly ash can substitute cement as much as possible only when its internal potential activity is fully stimulated. For this purpose, it is affirmatively necessary to study the excitation principle and mode of fly ash.
In the physical excitation mode, the particle size of fly ash is changed by mechanical milling technology, so its particle fineness is improved, and specific surface area is increased, which facilitates the dissolution of elements such as $\mathrm{SiO}_{2}$ and $\mathrm{Al}_{2} \mathrm{O}_{3}$ and the penetration of $\mathrm{Ca}^{2+}$, thereby improving the activity of fly ash $[10,11]$. As for the chemical excitation mode, different fly ash excitants are added to stimulate the internal potential activity of fly ash [12]. Fu et al. [13] developed a compound additive and its ratio to effectively activate fly ash by using the methods of orthogonal design and uniform design and working out a computer program. Sun et al. [14] studied the mechanism and persistence of different chemical excitants stimulating the activity of fly ash by using XRD, SEM, EDS, and other devices and determined the optimal combination of excitants by single mixing and double mixing. Hoang et al. [15] investigated the compressive strength of fly ash cement gelatin at $5^{\circ} \mathrm{C}$ and $20^{\circ} \mathrm{C}$ by using three different additives, that is, sodium thiocyanate, diethanolamine, and glycerin. The results showed that cement hydration is promoted after these three additives are added, and the content of calcium carboaluminate in hydration products is increased, and the 
compressive strength of gelatin is also improved to a certain extent.

$\mathrm{Al}_{2} \mathrm{O}_{3}$ and $\mathrm{SiO}_{2}$ stored in fly ash bind with $\mathrm{Ca}^{2+}$ in slurry to form calcium silicate and calcium aluminate, so that the internal structure of gelatin becomes denser, and its longterm strength is improved [16]. The reaction mechanism is as follows.
$\mathrm{CaO}$ in cement reacts with water to generate $\mathrm{Ca}(\mathrm{OH})_{2}$ :

$$
\mathrm{CaO}+\mathrm{H}_{2} \mathrm{O} \longrightarrow \mathrm{Ca}(\mathrm{OH})_{2}
$$

$\mathrm{Al}_{2} \mathrm{O}_{3}$ and $\mathrm{SiO}_{2}$ in fly ash continue to react chemically with $\mathrm{Ca}(\mathrm{OH})_{2}$ to generate $\mathrm{CaO} \cdot \mathrm{SiO}_{2}$ and $\mathrm{CaO} \cdot \mathrm{Al}_{2} \mathrm{O}_{3}$ :

$$
\begin{gathered}
m_{1} \cdot \mathrm{Ca}(\mathrm{OH})_{2}+\mathrm{SiO}_{2}+n \mathrm{H}_{2} \mathrm{O} \longrightarrow m_{1} \cdot \mathrm{CaO} \cdot \mathrm{SiO}_{2} \cdot n \mathrm{H}_{2} \mathrm{O} \\
m_{1} \cdot \mathrm{Ca}(\mathrm{OH})_{2}+\mathrm{Al}_{2} \mathrm{O}_{3}+n \mathrm{H}_{2} \mathrm{O} \longrightarrow m_{1} \cdot \mathrm{CaO} \cdot \mathrm{Al}_{2} \mathrm{O}_{3} \cdot n \mathrm{H}_{2} \mathrm{O}
\end{gathered}
$$

However, $\mathrm{Ca}^{2+}$ in slurry is not enough for $\mathrm{Al}_{2} \mathrm{O}_{3}$ and $\mathrm{SiO}_{2}$. Hence, excitant is added to the slurry to supplement $\mathrm{Ca}^{2+}$ needed by $\mathrm{Al}_{2} \mathrm{O}_{3}$ and $\mathrm{SiO}_{2}$ and also to crack the internal structure of fly ash. Then, the excitant reacts chemically with $\mathrm{Al}_{2} \mathrm{O}_{3}$ dissolved from fly ash in the solution containing $\mathrm{CaO}$ to generate ettringite (Aft). The reaction mechanism is as follows:

$$
\begin{gathered}
\mathrm{AL}_{2} \mathrm{O}_{3}+\mathrm{Ca}(\mathrm{OH})_{2}+12 \mathrm{H}_{2} \mathrm{O} \longrightarrow \mathrm{C}_{3} \mathrm{AH}_{12} \\
\mathrm{C}_{3} \mathrm{AH}_{12}+3 \mathrm{C} \bar{S} \mathrm{H}_{2}+14 \mathrm{H}_{2} \mathrm{O} \longrightarrow \mathrm{C}_{3} \mathrm{~A} \cdot 2 \mathrm{C} \bar{S} \mathrm{H}_{12}+\mathrm{Ca}(\mathrm{OH})_{2}
\end{gathered}
$$

Excitant is added to also increase the concentration of $\mathrm{OH}$ - in the slurry [17], so that the reaction speed between fly ash and $\mathrm{Ca}(\mathrm{OH})_{2}$ is improved. In addition, it also has a certain promoting effect on the early strength of gelatin. The reaction mechanism is as follows:

$$
\begin{gathered}
-\mathrm{O}-\mathrm{S}-\mathrm{OH}+\mathrm{NaOH} \longrightarrow-\mathrm{O}-\mathrm{Si}-\mathrm{ONa}+\mathrm{H}_{2} \mathrm{O} \\
-\mathrm{O}-\mathrm{Si}-\mathrm{O}-\mathrm{Si}+2 \mathrm{NaOH} \longrightarrow 2(-\mathrm{O}-\mathrm{Si}-\mathrm{ONa})+\mathrm{H}_{2} \mathrm{O}
\end{gathered}
$$

According to the above analysis, excitant can be added to densify the gelatin, generate more stable hydration products, and improve the compressive strength of gelatin.

\section{Composition of Test Materials}

The test materials used include fly ash produced by China Huadian Group Kunming Power Plant; 32.5\# Portland slag cement produced by Beikong Cement Plant; lime powder with calcium content $\geq 85 \%$ and fineness $\geq 180$ meshes produced by Kunming Maoshan Qiangda Lime Building Materials Factory; and gypsum powder produced by Yunnan Hongshi Mining Co., Ltd., as well as $\mathrm{NaOH}, \mathrm{Na}_{2} \mathrm{SO}_{4}$, and other chemical additives.

\section{Characteristics of Fly Ash}

The fly ash has a density of $1.8 \sim 2.3 \mathrm{~g} / \mathrm{cm}^{3}$, bulk density of $0.6 \sim 0.9 \mathrm{~g} / \mathrm{cm}^{3}$, measured bulk density of $0.79 \mathrm{~g} / \mathrm{cm}^{3}$, and compacted bulk density of $1.26 \mathrm{~g} / \mathrm{cm}^{3}$. Its chemical composition and technical indexes are shown in Tables 1 and 2 , respectively.

\section{Characteristics of Cement}

The cement has a density of $3.01 \sim 3.15 \mathrm{~g} / \mathrm{cm}^{3}$, bulk density of $1.3 \sim 1.8 \mathrm{~g} / \mathrm{cm}^{3}$, measured bulk density of $1.35 \mathrm{~g} / \mathrm{cm}^{3}$, and compacted bulk density of $1.95 \mathrm{~g} / \mathrm{cm}^{3}$. Its chemical composition is shown in Table 3.

4.1. Test Program. In this paper, four different excitants are used to perform compound activation test on fly ash. Because the activation effect on fly ash varies among different excitants, the test program is designed by the orthogonal test in this paper. According to a great number of preliminary studies, the four excitants used in this test are determined: lime, gypsum, $\mathrm{NaoH}$, and $\mathrm{Na}_{2} \mathrm{SO}_{4}$. $\mathrm{L} 9\left(3^{4}\right)$ orthogonal table is used for orthogonal test. The specific test programs are shown in Tables 4 and 5, respectively.

According to the test method by Huang et al. [18], the evenly mixed slurry is poured into a standard triple test mold $(7.07 \mathrm{~cm} * 7.07 \mathrm{~cm} * 7.07 \mathrm{~cm})$ and then cured for $24 \mathrm{~h}$ and demoulded after tamping. The specimen is watered every $3 \mathrm{~d}$ and covered with water-retaining material, and cured for $3 \mathrm{~d}$, $7 \mathrm{~d}$, and $28 \mathrm{~d}$ at room temperature.

The evenly mixed slurry is poured into a measuring cylinder with a measuring range of $200 \mathrm{~mL}$ until reaching the $100 \mathrm{~mL}$ scale. The bleeding amount of the slurry is recorded at $2 \mathrm{~h}$, and the bleeding rate is calculated according to formula (8) [19], where $V$ is the total volume of slurry; $\Delta V$ is the secreted water.

The slurry prepared is poured into a slump barrel with both top and bottom openings. The slump barrel is placed vertically upward and then lifted at a constant speed. The maximum diffusion diameter of the slurry, that is, the fluidity of slurry, is measured by a straight rule.

4.2. Test Equipment. The microstructure of fly ash cement gelatin and the morphology of its hydration products are observed by Philips XL30 ESEM-TMP SEM (Figure 1(a)) and D/Max 2200 XRD (Figure 1(b)) provided by Research Center for Analysis and Measurement, Kunming University of Science and Technology. 
TABLE 1: Chemical composition of fly ash.

\begin{tabular}{lccccccccc}
\hline Composition & $\mathrm{Fe}_{2} \mathrm{O}_{3}$ & $\mathrm{SiO}_{2}$ & $\mathrm{Al}_{2} \mathrm{O}_{3}$ & $\mathrm{CaO}$ & $\mathrm{MgO}$ & $\mathrm{Na}_{2} \mathrm{O}$ & $\mathrm{K}_{2} \mathrm{O}$ & $\mathrm{SO}_{3}$ & Loss on ignition \\
\hline Content (\%) & 11.26 & 51.79 & 22.95 & 2.89 & 1.6 & 0.46 & 0.9 & 0.06 & 7.69 \\
\hline
\end{tabular}

TABLE 2: Technical indexes of fly ash.

\begin{tabular}{lccc}
\hline Item & Unit of measurement & Technical index & Test value \\
\hline Fineness & $\%$ & $\leq 8(0.08$ screen residue $)$ & 1.1 \\
Loss on ignition & $\%$ & $\leq 5.0$ & 7.69 \\
Water demand & $\%$ & $\leq 95$ & 90 \\
Water content & $\%$ & $\leq 1.0$ & 0.03 \\
SO3 & $\%$ & $\leq 3.0$ & 0.06 \\
Free $\mathrm{CaO}$ & $\%$ & $\leq 4.0$ & Trace amount \\
\hline
\end{tabular}

TABle 3: Chemical composition of P.S 32.5 cement.

\begin{tabular}{lcccccrrr}
\hline Composition & $\mathrm{SiO}_{2}$ & $\mathrm{Al}_{2} \mathrm{O}_{3}$ & $\mathrm{Fe}_{2} \mathrm{O}_{3}$ & $\mathrm{CaO}$ & $\mathrm{MgO}$ & $\mathrm{K}_{2} \mathrm{O}$ & $\mathrm{SO}_{3}$ & $\mathrm{Total}$ \\
\hline Content (\%) & 19.97 & 6.34 & 3.74 & 65.74 & 1.11 & 1.1 & 0.12 & 98.12 \\
\hline
\end{tabular}

TABLE 4: Orthogonal table design of compound activation test.

\begin{tabular}{lcccc}
\hline Level & $\mathrm{A}$ & $\mathrm{B}$ & $\mathrm{C}$ & $\mathrm{D}$ \\
\hline & Lime dosage (\%) & Gypsum dosage (\%) & $\mathrm{NaOH}$ dosage (\%) & $\mathrm{Na}_{2} \mathrm{SO}_{4}$ dosage $(\%)$ \\
1 & 8 & 4 & 1 & 2 \\
2 & 12 & 5 & 2 & 3 \\
3 & 16 & 6 & 3 & 4 \\
\hline
\end{tabular}

TABLE 5: Orthogonal test scheme of compound activation.

\begin{tabular}{|c|c|c|c|c|}
\hline Test no. & $\begin{array}{c}\text { A } \\
\text { Lime dosage (\%) }\end{array}$ & $\begin{array}{c}\text { B } \\
\text { Gypsum dosage (\%) }\end{array}$ & $\begin{array}{c}\mathrm{C} \\
\mathrm{NaOH} \text { dosage (\%) }\end{array}$ & $\begin{array}{c}\mathrm{D} \\
\mathrm{Na}_{2} \mathrm{SO}_{4} \text { dosage (\%) }\end{array}$ \\
\hline FH-1 & 8 & 4 & 1 & 2 \\
\hline FH-2 & 8 & 5 & 2 & 3 \\
\hline $\mathrm{FH}-3$ & 8 & 6 & 3 & 4 \\
\hline $\mathrm{FH}-4$ & 12 & 4 & 2 & 4 \\
\hline $\mathrm{FH}-5$ & 12 & 5 & 3 & 2 \\
\hline FH-6 & 12 & 6 & 1 & 3 \\
\hline FH-7 & 16 & 4 & 3 & 3 \\
\hline $\mathrm{FH}-8$ & 16 & 5 & 1 & 4 \\
\hline FH-9 & 16 & 6 & 2 & 2 \\
\hline
\end{tabular}

Notes: the ratio of cement to fly ash is $1: 1$; the water-cement ratio is 0.5 .

\section{Analysis of Test Results}

5.1. Fluidity Analysis of Slurry. According to Table 6, slurry containing the system of excitant and fly ash has a bleeding rate of $2.24 \% \sim 3.73 \%$ and a fluidity of $110 \mathrm{~mm} 155 \mathrm{~mm}$. The bleeding rate and fluidity of unmixed cement mortar are $9.25 \%$ and $150 \mathrm{~mm}$, respectively. According to field filling experience, the slurry has a paste property if its bleeding rate is below $5 \%$ [20]. Therefore, it is believed that the system of excitant and fly ash can be added to improve the fluidity of slurry and ensure that no segregation or pipe blockage occurs during the slurry transportation. The primary cause is that although the lime used in the test is hydrated lime $\left(\mathrm{Ca}(\mathrm{OH})_{2}\right)$, it still contains a small amount of quicklime $(\mathrm{CaO})$. The digestion reaction between $\mathrm{CaO}$ and water continues to generate $\mathrm{Ca}(\mathrm{OH})_{2}$, and $\mathrm{Ca}(\mathrm{OH})_{2}$ particles are in the form of colloidal dispersion. The diameter of these particles is about $1 \mathrm{~m}$, and their surface is covered by a thick water film. As indicated by a large number of particles and large total surface area, lime has a good water-retaining property, so that the slurry has a certain stability without excess water secretion. There is no big difference in fluidity between unmixed cement mortar and slurry containing the system of excitant and fly ash, so no detailed analysis is conducted, and only the bleeding rate of slurry is analyzed by multiple linear regression and variance analysis, as shown in the following formula:

$$
y=4.32-13.67 x_{1}-2.5 x_{2}+6.5 x_{3}+9 x_{4},
$$

where $y$ is the bleeding rate of slurry; $x_{1}$ is the lime dosage, $\%$; $x_{2}$ is the gypsum dosage, $\% ; x_{3}$ is the $\mathrm{NaOH}$ dosage, $\% ; x_{4}$ is the $\mathrm{Na}_{2} \mathrm{SO}_{4}$ dosage.

The negative correlation coefficient $\mathrm{R}^{2}$ of curve fitting is 0.848 , indicating that the regression of this equation is significant and the curve fitting is highly accurate. 


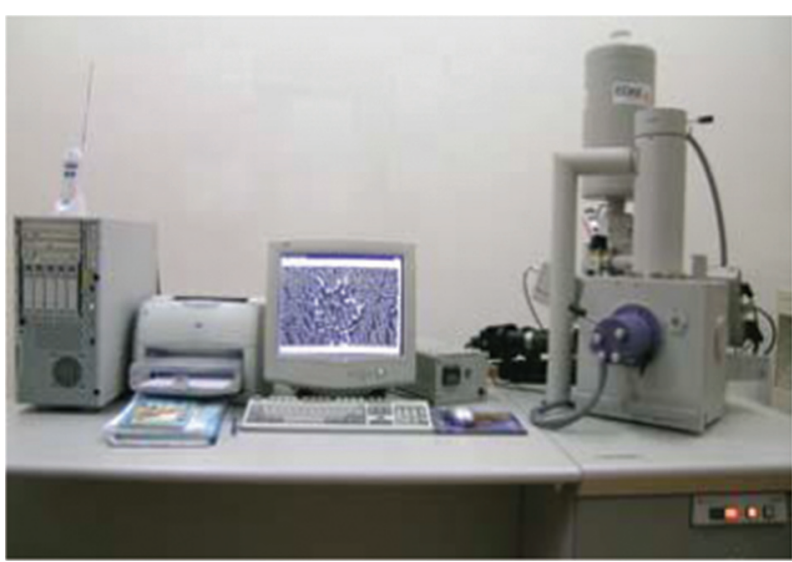

(a)

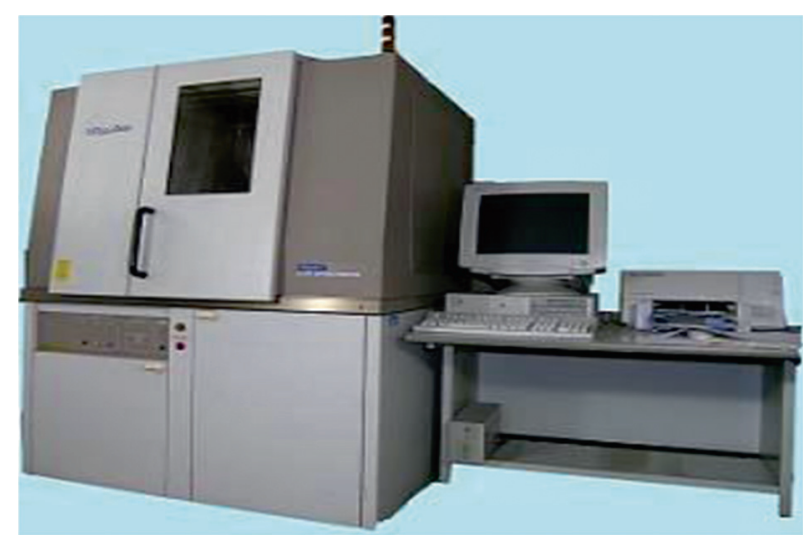

(b)

FIgure 1: Morphology and phase test. (a) SEM. (b) XRD.

TABLE 6: Rheological properties of slurry.

\begin{tabular}{|c|c|c|c|c|c|c|}
\hline Test No. & $\begin{array}{c}\text { A } \\
\text { Lime dosage }(\%)\end{array}$ & $\begin{array}{c}\text { B } \\
\text { Gypsum dosage (\%) }\end{array}$ & $\begin{array}{c}\mathrm{C} \\
\mathrm{NaOH} \text { dosage (\%) }\end{array}$ & $\begin{array}{c}\mathrm{D} \\
\mathrm{Na}_{2} \mathrm{SO}_{4} \text { dosage (\%) } \\
\end{array}$ & Syneresis rate (\%) & $\begin{array}{l}\text { Fluidity } \\
(\mathrm{mm})\end{array}$ \\
\hline FH-1 & $1(8)$ & $1(4)$ & $1(1)$ & $1(2)$ & 3.47 & 131 \\
\hline $\mathrm{FH}-2$ & 1 & $2(5)$ & $2(2)$ & $2(3)$ & 3.17 & 140 \\
\hline $\mathrm{FH}-3$ & 1 & $3(6)$ & $3(3)$ & $3(4)$ & 3.73 & 155 \\
\hline FH-4 & $2(12)$ & 1 & 2 & 3 & 3.14 & 145 \\
\hline FH-5 & 2 & 2 & 3 & 1 & 3.02 & 138 \\
\hline FH-6 & 2 & 3 & 1 & 2 & 2.94 & 115 \\
\hline FH-7 & $3(16)$ & 1 & 3 & 2 & 2.45 & 136 \\
\hline FH-8 & 3 & 2 & 1 & 3 & 2.4 & 112 \\
\hline FH-9 & 3 & 3 & 2 & 1 & 2.24 & 110 \\
\hline KD-12 & 0 & 0 & 0 & 0 & 9.25 & 150 \\
\hline
\end{tabular}

Notes: KD-12 is unmixed cement mortar; KD-11 is fly ash containing 50 additives, without excitant.

Variance analysis is carried out on the bleeding rate of slurry. According to Table 6, the influence of each factor on the bleeding rate of slurry from big to small is as follows: lime dosage $>\mathrm{NaOH}$ dosage $>\mathrm{Na}_{2} \mathrm{SO}_{4}$ dosage $>$ gypsum dosage; the optimal scheme is $\mathrm{A}_{3} \mathrm{~B}_{2} \mathrm{C}_{2} \mathrm{D}_{2}$, that is, $16 \%$ lime, $5 \%$ gypsum, $2 \% \mathrm{NaOH}$, and $3 \% \mathrm{Na}_{2} \mathrm{SO}_{4}$ (due to limited space, variance analysis is not described).

5.2. Strength Analysis of Fly Ash Cement Gelatin. For some specimens that have reached the curing period, the compressive strength test is carried out by 200-C-1 compression-testing machine manufactured by Wuxi Building Materials Instrument Factory, and the test results are shown in Figure 2. Other specimens are divided by a cutting machine, and a small part in the middle is retained and placed in industrial alcohol to stop its hydration reaction. When necessary, the specimen is taken out and carbon sprayed on its surface, and then it can be scanned by SEM [21].

According to Figure 2, when the curing period is only $3 \mathrm{~d}$, the addition of excitant can improve the compressive strength of fly ash cement gelatin, but its maximum strength value is far less than that of ordinary Portland cement. According to Figure 3, with the increase of curing period and when it reaches $7 \mathrm{~d}$, the strength value of the gelatin containing the system of excitant and fly ash is $68 \% \sim 85 \%$, and that of the gelatin without excitant is $46 \% \sim 60 \%$. When the curing period reaches $28 \mathrm{~d}$, the strength value of the gelatin containing the system of excitant and fly ash is $37 \% \sim 78 \%$, and that of the gelatin without excitant is $35 \% \sim 68 \%$. Therefore, excitant can be added to increase the hydration speed of fly ash and enhance the compressive strength of fly ash cement gelatin. When the curing period reaches $90 \mathrm{~d}$ or $180 \mathrm{~d}$, the compressive strength of gelatin containing the system of excitant and fly ash is greater than that of ordinary Portland cement.

Multivariate linear regression analysis and variance analysis are carried out on the compressive strength of gelatin containing the system of excitant and fly ash at $3 \mathrm{~d}$, $7 \mathrm{~d}$, and $28 \mathrm{~d}$, as shown in formulas (9)-(11):

$$
y=0.45+0.02 x_{1}-0.06 x_{2}+0.28 x_{3}+0.04 x_{4} .
$$

The $F$-value test method is adopted, and the critical value of F-test is $F_{0.95}(4.5)=5.19<F=61.95$. The regression equation is significant and the negative correlation coefficient $R_{2}=0.9644$, where $y$ is the compressive strength of gelatin; $x_{1}$ is the lime dosage, $\% ; x_{2}$ is the gypsum dosage, $\%$; $x_{3}$ is the $\mathrm{NaoH}$ dosage, $\% ; x_{4}$ is the $\mathrm{Na}_{2} \mathrm{SO}_{4}$ dosage.

$$
y=4.62+0.001 x_{1}-0.41 x_{2}+1.63 x_{3}-0.23 x_{4} \text {. }
$$

The $F$-value test method is adopted, and the critical value of $F$-test is $F_{0.95} \quad(4.5)=5.19<F=71.12$. The 


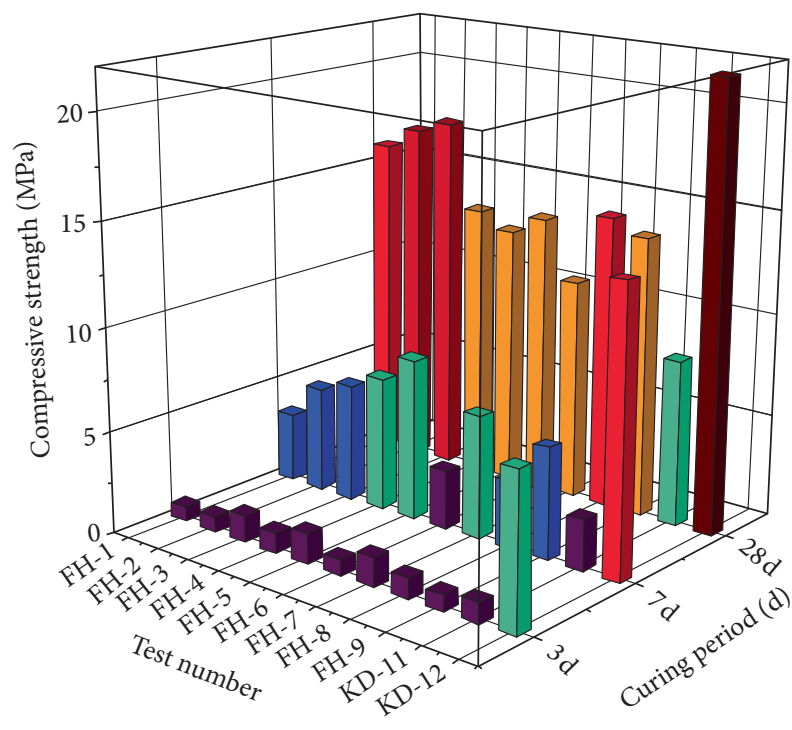

FIGURE 2: Variation of compressive strength of cementitious materials with different ratios.

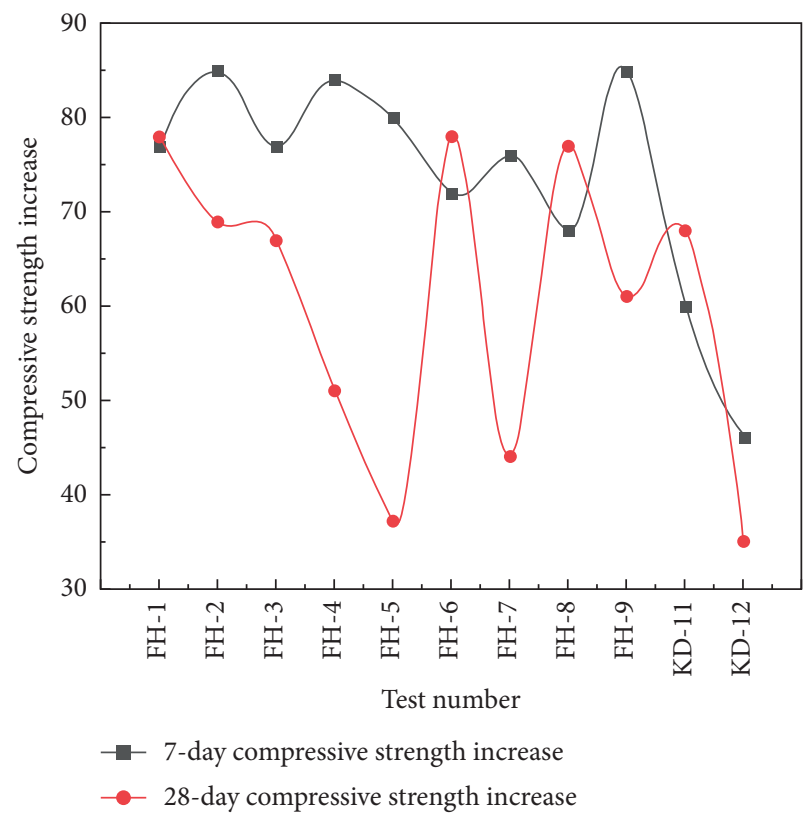

FIGURE 3: Increase of compressive strength with curing age.

regression equation is significant and the negative correlation coefficient $R_{2}=0.9689$, where $y$ is the compressive strength of gelatin; $x_{1}$ is the lime dosage, $\% ; x_{2}$ is the gypsum dosage, $\% ; x_{3}$ is the $\mathrm{NaoH}$ dosage, $\% ; x_{4}$ is the $\mathrm{Na}_{2} \mathrm{SO}_{4}$ dosage.

$$
y=16.24-0.49 x_{1}+0.72 x_{2}-0.50 x_{3}+0.46 x_{4} .
$$

The $F$-value test method is adopted, and the critical value of F-test is F0.95 $(4.5)=5.19<\mathrm{F}=302.44$. The regression equation is significant and the negative correlation coefficient $R_{2}=0.99259$, where $y$ is the compressive strength of gelatin; $x_{1}$ is the lime dosage, $\% ; x_{2}$ is the gypsum dosage, $\% ; x_{3}$ is the $\mathrm{NaOH}$ dosage, \%; $x_{4}$ is the $\mathrm{Na}_{2} \mathrm{SO}_{4}$ dosage.
Variance analysis is carried out on the compressive strength of gelatin containing the system of excitant and fly ash at $3 \mathrm{~d}, 7 \mathrm{~d}$, and $28 \mathrm{~d}$, and the analysis results are shown in Table 7. According to Table 7, the fluence of each factor on the early strength of gelatin from big to small is as follows: $\mathrm{NaOH}$ dosage $>$ lime dosage $>\mathrm{Na}_{2} \mathrm{SO}_{4}$ dosage $>$ gypsum dosage. The optimal scheme is $\mathrm{A}_{2} \mathrm{~B}_{2} \mathrm{C}_{3} \mathrm{D}_{3}$ or $\mathrm{A}_{3} \mathrm{~B}_{2} \mathrm{C}_{3} \mathrm{D}_{3}$ (the influence and optimal scheme for gelatin with a curing period of $7 \mathrm{~d}$ and $3 \mathrm{~d}$ are the same, so they are not listed). The influence on long-term strength from big to small is as follows: lime dosage $>$ gypsum dosage $>\mathrm{Na}_{2} \mathrm{SO}_{4}$ dosage $>\mathrm{NaOH}$ dosage, and the optimal scheme is $\mathrm{A}_{1} \mathrm{~B}_{3} \mathrm{C}_{2} \mathrm{D}_{3}$.

\section{Analysis of Gelatin Morphology and Phase Test Results}

6.1. SEM Analysis of Hydration Products. According to Figure 4(a), the solid particles in the slurry are uniformly dispersed in the fly ash cement gelatin without the addition of excitant upon the curing period of $3 \mathrm{~d}$. There are few hydration products, and only a small amount of C-S-H flocs and tabular $\mathrm{Ca}(\mathrm{OH})_{2}$ are produced, leading to loose gelatin structure and no stable structure. According to Figure 4(b), compared with gelatin at $3 \mathrm{~d}$, the gelatin at $28 \mathrm{~d}$ has a large amount of acicular AFt, which extend and cross each other to form a denser network structure.

According to Figure 5(a), although the curing period of gelatin containing excitant is only $3 \mathrm{~d}$, the solid particles have been wrapped by hydration products, and the particles are connected through AFt to form a dense network structure. Compared with Figure 4(a), the hydration of fly ash is obviously improved, the hydration products are increased, the network structure formed is more complex, and the gelatin is more dense. According to Figure 5(b) in which excitant is added, compared with Figure 4(b), the hydration of the gelatin is more significant, the internal structure is denser, and the hydration products are more complex, mainly including C-S-H gelatin, $\mathrm{AFt}, \mathrm{Ca}(\mathrm{OH})_{2}$, and $\mathrm{CaCO}_{3}$. In addition, $\mathrm{AFt}$ becomes thicker and denser, so that all particles are tightly connected into one piece, and no obvious gap can be seen.

6.2. XRD Analysis of Hydration Products. As can be seen from Figure 6(a), the hydration reaction of the specimen after curing for $3 \mathrm{~d}$ generates substances such as $\mathrm{Ca}(\mathrm{OH})_{2}(\mathrm{C}), \mathrm{AFt}(\mathrm{E})$, and C-S-H gelatin. With the increase of hydration cycle, the diffraction peak of $\mathrm{Ca}(\mathrm{OH})_{2}$ decreases obviously, which is mainly due to the chemical reaction between $\mathrm{Ca}(\mathrm{OH})_{2}$ and quartz $(\mathrm{Q})$ or mullite in fly ash, resulting in new hydration products. However, the diffraction peak of AFt basically has no change, which indicates that the reaction speed of fly ash is slow without excitant, resulting in a low growth in the strength of gelatin.

As can be seen from Figure 7(a), since the excitant contains $\mathrm{Ca}(\mathrm{OH})_{2}$, the diffraction peak of $\mathrm{Ca}(\mathrm{OH})_{2}$ in Figure 7(a) is higher than that of $\mathrm{Ca}(\mathrm{OH})_{2}$ in Figure 6(a). Therefore, gelatin with $t$ excitant has a greater early strength. The diffraction peak of $\mathrm{Ca}(\mathrm{OH})_{2}$ in Figure $7(\mathrm{~b})$ is obviously lower than that of $\mathrm{Ca}(\mathrm{OH})_{2}$ in Figure $7(\mathrm{a})$, and the 
TABLE 7: Analysis results of orthogonal test for compressive strength of slurry.

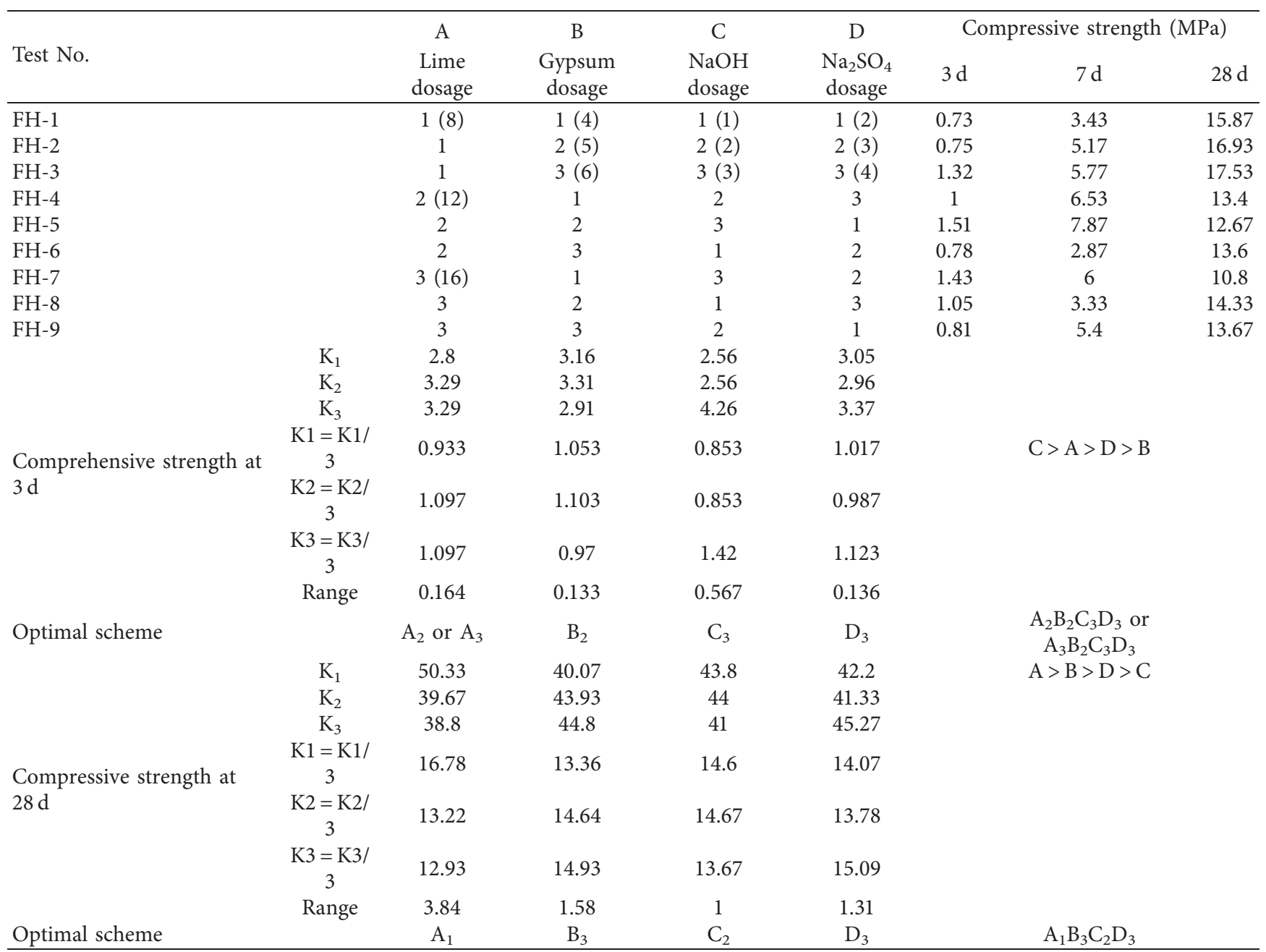

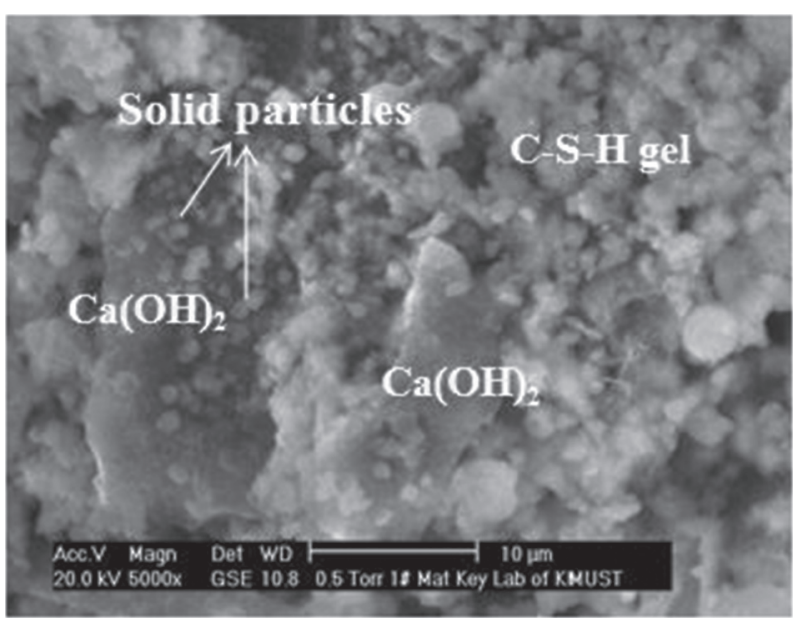

(a)

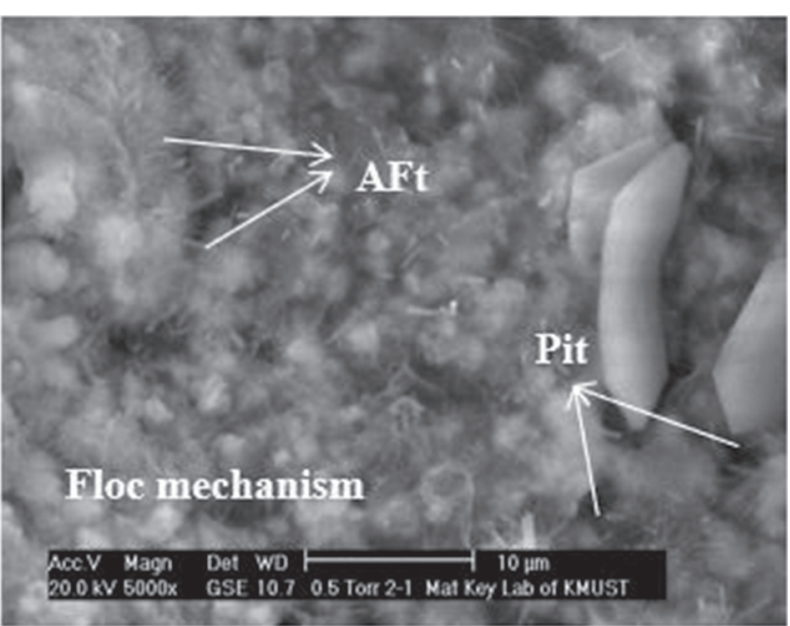

(b)

Figure 4: Microstructure of cementite after 3 days and 28 days when fly ash content is 50\% without activator. (a) $3 \mathrm{~d}$ curing period; (b) $28 \mathrm{~d}$ curing period. 


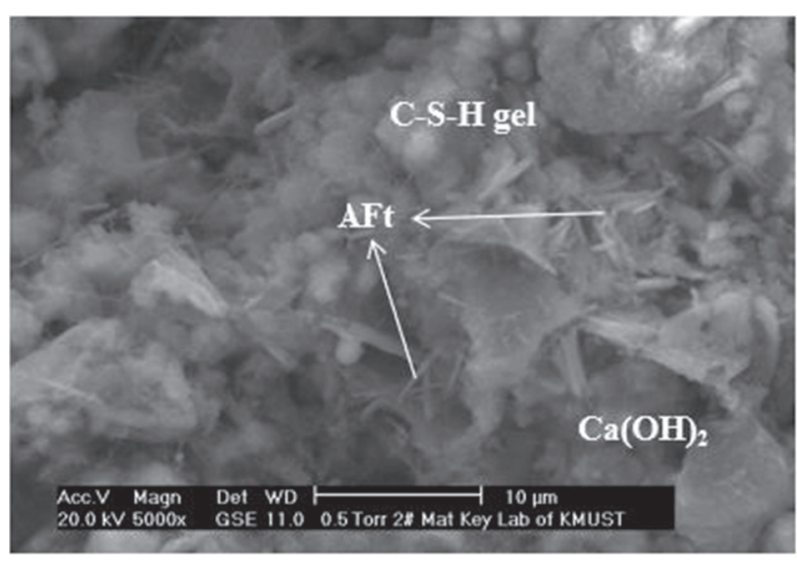

(a)

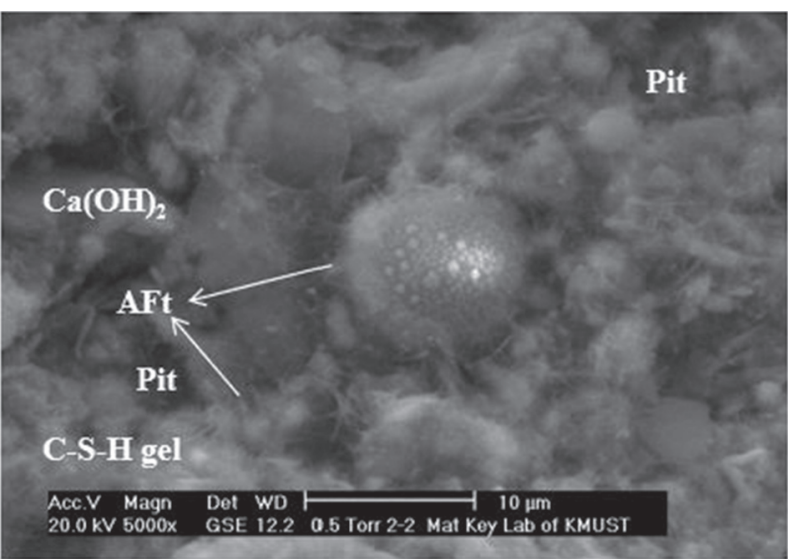

(b)

FIgURE 5: Microstructure of cementitious body after 3 days and 28 days with $50 \%$ fly ash and activator. (a) $3 \mathrm{~d}$ curing period; (b) $28 \mathrm{~d}$ curing period.

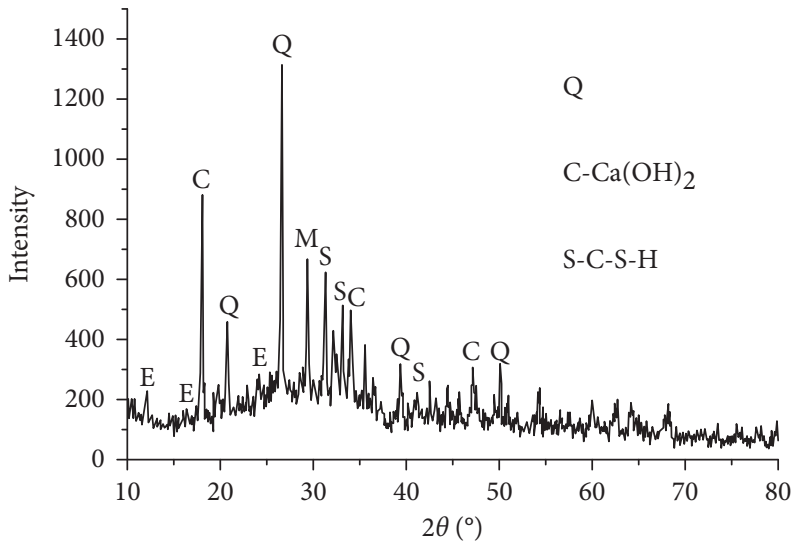

(a)

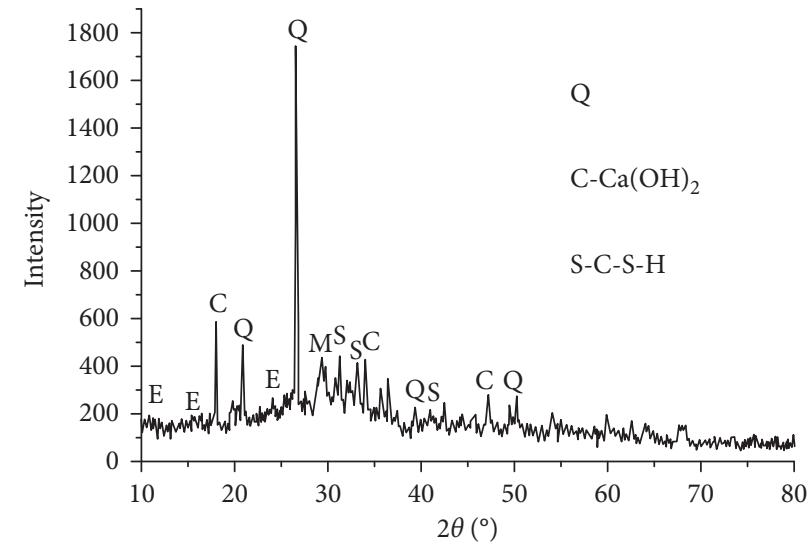

(b)

FIGURE 6: XRD patterns of hydration products at different ages with 50\% fly ash without activator. (a) 3-day hydration; (b) 28-day hydration.

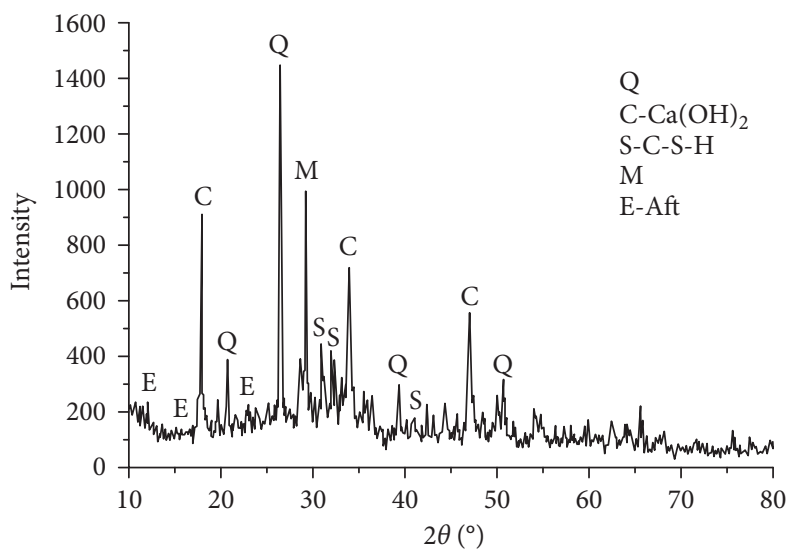

(a)

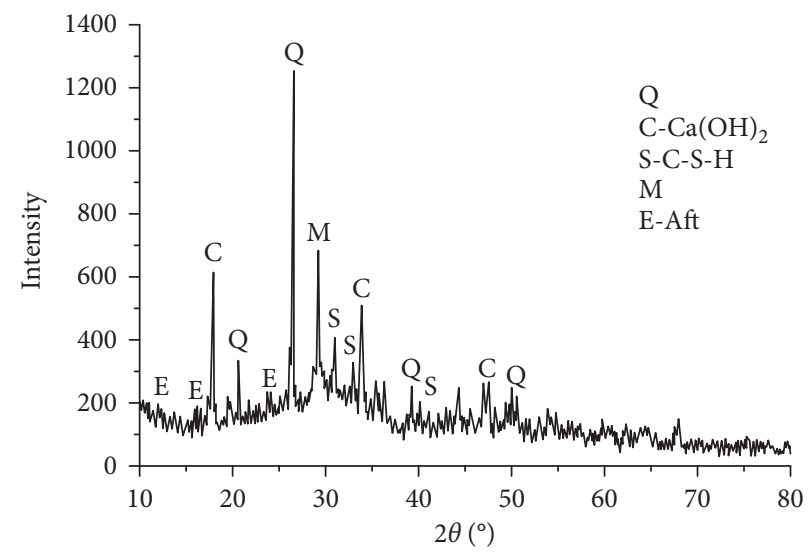

(b)

FIGURE 7: XRD patterns of hydration products with 50\% fly ash and activator at different ages. (a) 3-day hydration; (b) 28-day hydration. 
diffraction peaks of mullite, quartz, and other substances in Figure 7(b) are all decreased. This is mainly because as the excitant is added, the active $\mathrm{SiO}_{2}$ released from quartz reacts with $\mathrm{Ca}(\mathrm{OH})_{2}$ in the slurry to form complex hydration products and increase the compressive strength of gelatin. The diffraction peak of $\mathrm{Ca}(\mathrm{OH})_{2}$ in Figure 7(b) is significantly lower than that of $\mathrm{Ca}(\mathrm{OH})_{2}$ in Figure $7(\mathrm{a})$, and the diffraction peaks of mullite, Shi Ying, and other substances in Figure 7(b) have all decreased. This is mainly due to the pozzolanic reaction between the active $\mathrm{SiO}_{2}$ released from and $\mathrm{Ca}(\mathrm{OH})_{2}$ in the slurry due to the addition of activator, which forms more complex hydration products and increases the compressive strength of the gel.

\section{Conclusions}

(1) The bleeding rate of slurry containing the system of excitant and fly ash is $2.24 \% \sim 3.73 \%$, which is far less than that of unmixed cement mortar (9.25\%). Its fluidity is $110 \mathrm{~mm} \sim 155 \mathrm{~mm}$, which is not much different from that of unmixed cement mortar $(150 \mathrm{~mm})$. The influence of four excitants on the bleeding rate of slurry from big to small is lime dosage $>\mathrm{NaOH}>\mathrm{Na}_{2} \mathrm{SO}_{4}>$ gypsum dosage, and the optimal scheme is $\mathrm{A}_{3} \mathrm{~B}_{2} \mathrm{C}_{2} \mathrm{D}_{2}$.

(2) The influence of each factor on the early strength of gelatin from big to small is $\mathrm{NaOH}$ dosage $>$ lime dosage $>\mathrm{Na}_{2} \mathrm{SO}_{4}$ dosage $>$ gypsum dosage, and the optimal scheme is $\mathrm{A}_{2} \mathrm{~B}_{2} \mathrm{C}_{3} \mathrm{D}_{3}$ or $\mathrm{A}_{3} \mathrm{~B}_{2} \mathrm{C}_{3} \mathrm{D}_{3}$. The influence on long-term strength from big to small is lime dosage $>$ gypsum dosage $>\mathrm{Na}_{2} \mathrm{SO}_{4}$ dosage $>\mathrm{NaOH}$ dosage, and the optimal scheme is $\mathrm{Al}_{3} \mathrm{C}_{2} \mathrm{D}_{3}$. The amount of excitant can be determined according to the strength requirements of the filling body.

(3) From the microstructure of gelatin, it can be seen that the addition of excitant makes the hydration products of fly ash more complex, mainly including C-S-H gelatin, $\mathrm{AFt}, \mathrm{Ca}(\mathrm{OH})_{2}$, and $\mathrm{CaCO}_{3}$. In addition, with the increase of curing period, AFt becomes denser and coarser, so that the particles are tightly connected into one piece without obvious gap, and the internal structure is denser. The results of XRD analysis show that excitant can be added to stimulate the activity of fly ash, generate more complex hydration products, and increase the compressive strength of fly ash cement gelatin.

(4) According to test results, it is considered that the addition of excitant fly ash system can improve the fluidity of slurry, increase the long-term strength of filling body, and reduce its early strength. The added amount of compound excitant can be appropriately adjusted according to the needs of the mines, thereby achieving the purpose of controlling the strength of filling body.

\section{Data Availability}

The data used to support the findings of this study are included within the article.

\section{Conflicts of Interest}

The authors declare that there are no conflicts of interest.

\section{Acknowledgments}

The authors thank the support of the Scientific Research Fund Project of Yunnan Provincial Department of Education on the Improvement of Public Safety Emergency Response Capacity by Large Numbers of Technologies-A Case Study of COVID-19 Epidemic (Project no. 2021J0961) and Teacher Research Fund Project of Yunnan Land and Resources Vocational College "Optimization Design of Ventilation and Dust Removal in Tunnel Construction Site Based on Fluent" (Project no. 2019YJ04)

\section{References}

[1] D. Y. Gao, Z. Liu, and Z.L. Cheng, "2D Ni-Fe MOF nanosheets reinforced poly(vinyl alcohol) hydrogels with enhanced mechanical and tribological performance," Colloids and Surfaces A: Physicochemical and Engineering Aspects, vol. 610, pp. 1259-1264, 2021.

[2] J. Liu, Z. Zhou, A. Wu, and Y. M. Wang, "Preparation and hydration mechanism of low concentration bayer red mud filling materials," Chinese Journal of Engineering, vol. 42, no. 11, pp. 1457-1464, 2020.

[3] X. Guo, X. Guo, S. Xin, and Y. Liu, "Zeolite from coal fly ash by hydrothermal synthesis and characterization," Bulletin of the Chinese Ceramic Society, vol. 35, no. 2, pp. 525-528, 2016.

[4] S. Amulya, A. U. Ravi Shankar, and M. Praveen, "Stabilisation of lithomargic clay using alkali activated fly ash and ground granulated blast furnace slag," International Journal of Pavement Engineering, vol. 21, no. 9, pp. 1114-1121, 2020.

[5] S. Kumar, P. Murthi, A. Paul, G. Ravindran, and S. Kumar, "Impact resistance and strength development of fly ash based self-compacting concrete," Silicon, no. 19, pp. 1-12, 2020.

[6] V. Saraswathy, S. Muralidharan, K. Thangavel, and S. Srinivasan, "Influence of activated fly ash on corrosionresistance and strength of concrete," Cement and Concrete Composites, vol. 25, no. 7, pp. 673-680, 2003.

[7] B. Wang, L. Zhang, J. Zhao et al., "Activation experiment study on high volume fly ash filling material," Coal Engineering, vol. 46, no. 10, pp. 192-195, 2016.

[8] D. Wu, B. Yang, and L. Yucheng, "Transportability and pressure drop of fresh cemented coal gangue-fly ash backfill(CGFB) slurry in pipe loop," Powder Technology, vol. 284, pp. 218-224, 2015.

[9] B. Yin, T. Kang, J. Kang et al., "The research of the hydration kinetics process and hydration mechanism of fly ash paste filling materials," Chinese Journal of Rock Mechanics and Engineering, vol. 37, no. 2, pp. 4384-4394, 2018.

[10] M. Mollamahmutoğlu and Y. Yilmaz, "Potential use of fly ash and bentonite mixture as liner or cover at waste disposal areas," Environmental Earth Sciences, vol. 40, no. 11-12, pp. 1316-1324, 2001.

[11] L. Zhongtao, M. A. Baoguo, Y. Jiujun et al., "Effects of fineness on activity character of fly ash," Advanced Materials Research, vol. 266, pp. 114-117, 2011.

[12] L. S. Zhang, G. H. Li, W. Huang, X. C. He, F. Jiang, and T. C. Liu, "The effect of slate powder on fly ash in suppressing alkali activity of slate aggregate," Applied Mechanics and Materials, vol. 357-360, pp. 1450-1454, 2013. 
[13] D. Fu, Study on Activation of Fly Ash and its Application in Grouting Engineering, Central South University, Hunan, China, 2003.

[14] G. Sun, Q. Tang, L. Zhang, and C. Wang, "Early activation effect and mechanism of high-volume fly ash," Journal of Harbin Engineering University, vol. 40, no. 3, pp. 540-547, 2019.

[15] K. Hoang, H. Justnes, and M. Geiker, "Early age strength increase of fly ash blended cement by a ternary hardening accelerating admixture," Cement and Concrete Research, vol. 81, pp. 59-69, 2016.

[16] M. Zhang and J. Yang, "Study on the application of excitant in cement gelatin with high volume fly-ash," Materials Reports, vol. 21, no. 6, pp. 146-148, 2017.

[17] H. L. Wang and X. D. Zhang, "Study on the effect of fly ash mix amount in large volume pile cap concrete on heat of hydration," Applied Mechanics and Materials, vol. 744-746, pp. 832-836, 2015.

[18] S. Huang, J. Jiang, N. Yang et al., Contemporary Concrete Technology, Science and Technology Press, Xi'an, Shaanxi, China.

[19] H. Jiao, A. Wu, H. J. Wang, X.-H. Liu, S. K. Yang, and Y. T. Xiao, "Experiment study on the flocculation settlement characteristic of unclassified tailings," Journal of University of Science and Technology Beijing, vol. 32, no. 12, pp. 1437-1441, 2011.

[20] A. Wu and H. Wang, Theory and Technology of Paste Filling in Metal Ore, Science Press, Beijing, China, 2015.

[21] L. Dong, Q. Gao, S. Nan, and J. Du, "Performance and hydration mechanism of new super fine cemented whole-tailings backfilling materials," Journal of Central South University (Science and Technology), vol. 44, no. 4, pp. 1571-1577, 2013. 